\title{
They are Trained to Teach, But How Confident are they? A Study of Student Teachers' Sense of Efficacy
}

\author{
${ }^{1}$ Bakar, A.R., ${ }^{2}$ S. Mohamed and ${ }^{1}$ N.S. Zakaria \\ ${ }^{1}$ Department of Education, Faculty of Educational Studies, University Putra Malaysia, Malaysia \\ ${ }^{2}$ Department of Matematics, Faculty of Science, Universiti Putra Malaysia, Malaysia
}

\begin{abstract}
The objective of the study was to assess student teachers' efficacy in one of the teacher training institutions in Malaysia, with specific reference to the aspects of student engagement, instructional strategies and classroom management. The sample size was 675 final-year teacher education students. The findings suggest that a majority of the respondents had a high level of teaching efficacy $(\mathrm{M}=3.98$; $\mathrm{SD}=0.36)$. They were also highly efficacious in student engagement $(\mathrm{M}=4.01 ; \mathrm{SD}=0.41)$, instructional strategies $(\mathrm{M}=4.01 ; \mathrm{SD}=0.39)$ and classroom management $(\mathrm{M}=4.00 ; \mathrm{SD}=0.45)$. A significant correlation was found between teaching efficacy and academic achievement $\mathrm{C}(\mathrm{r}=0.15$, $\mathrm{p}<0.05)$. The study also revealed that teaching efficacy differed as a function of gender $(\mathrm{t}=6.47$, $\mathrm{p}<0.05)$, career choice $(\mathrm{t}=6.04, \mathrm{p}<0.05)$, educational aspiration $(\mathrm{t}=2.02, \mathrm{p}<0.05)$ and content major $\left(\mathrm{F}_{3,668}=9.86, \mathrm{p}<0.05\right)$.
\end{abstract}

Keywords: Student Teachers, Teacher Sense of Efficacy, Malaysian Student Teachers

\section{INTRODUCTION}

Research affirms that teacher quality is the most important factor in predicting student outcomes (Owings et al., 2006). As noted by the NA (2007), teacher quality is widely recognized by the policymakers, practitioners and researchers alike to be the most powerful influence on a student's academic performance. A cross-sectional analysis of the 2003 Trends in International Mathematics and Science Study data across 46 countries showed that countries with better quality teachers produced higher mathematics achievement compared to those with poor quality teachers (Akiba et al., 2007). Numerous studies on teacher quality (Darling-Hammond and Youngs, 2002; Rice, 2003; Wayne and Youngs, 2003) have been reported and most of these studies focused on teacher certification, subject-matter knowledge, pedagogical knowledge and teaching experience, since these qualities of teachers are associated with high student achievement. Recognizing the importance of teacher quality, Cohen-Vogel (2005) noted that teachers' improvement has been the major focus of educational reforms in the past 50 years.

Teacher quality standards are extremely sophisticated and illustrate the wide range of knowledge, skills, abilities and dispositions that, cotemporary educators believe, competent teachers must possess and demonstrate in the classroom (Mitchell et al., 2001). It is, therefore, the responsibility of a teacher training institution to prepare pre-service teachers to become highly effective teachers. It is believed that pedagogical knowledge, skills and content knowledge alone cannot prepare them to become quality teachers.

High quality teaching is not based merely on what teachers know but also on what teachers do (CTQ, 2006). Quality teachers are those who are able to deliver the lesson with great confidence, resulting in positive learning outcomes. Roberts (2006) explained that effective teachers are those who support students' interests and challenge students in making their decisions about their career interest. Thus, in addition to acquiring Corresponding Author: Bakar, A.R., Department of Education, Faculty of Educational Studies, University Putra Malaysia, Malaysia 
content and pedagogical knowledge and skills, teachers should have confidence in delivering the knowledge and skills to students in order to bring about more positive learning outcomes. The belief of a teacher's ability to execute the course of action required to successfully accomplish a specific task in a particular context is defined as "teacher efficacy" (Tschannen-Moran et al., 1998). Teacher's sense of efficacy is an important attribute a teacher training institution cannot tend to ignore. According to Knoblauch and Hoy (2008), to be effective, teachers need more than content and pedagogical knowledge. These authors have put forth compelling evidences to support the influence of teacher's sense of efficacy on teaching effectiveness. Teacher self-efficacy was found to be related to classroom management, use of teaching techniques and enhancement of student mastery of cognitive and affective goals (Garcia, 2004). Yost (2002) posited that highly efficacious teachers tend to provide the most beneficial learning environment for students.

Teachers' sense of efficacy plays a great role in dealing with students and probably more important than anything else. Studies of Early et al. $(2006 ; 2007)$ and Justice et al. (2008) point to the fact that teacher's qualifications, academic majors and general credentials have no association with improved classroom quality or student academic achievement. Justice et al. (2008) and Guo et al. (2010) found that teacher's sense of efficacy is associated with higher quality of classroom instructions and increased student achievement. According to Bandura (1986; 1997), those who believe they will be successful on a given task are more likely to achieve the desired goals because they allocate substantial efforts, persist in the face of setbacks and develop coping mechanisms for managing negative events. There are many other benefits in being highly efficacious. Teachers with a high sense of efficacy exhibit greater enthusiasm in teaching (Allinder, 1994; Hall et al., 1992). They tend to be less critical of students who make errors (Ashton and Webb, 1986), spend more time with students who are struggling (Gibson and Dembo, 1984) and tend to exhibit greater levels of planning and organization (Milner, 2001). They are committed (Colodarci, 1992) and will stay in this profession longer (Milner, 2002; Allinder, 1994).

According to Woolfolk-Hoy (2000), development of self-efficacy is essential for producing effective, committed and enthusiastic teachers. The process of developing efficacy in teachers is a key element in teacher education programs, chiefly guided by university supervisors and cooperating teachers. As reported by Darling-Hammond et al. (2002), there was a significant association between teachers' ratings of their overall preparedness and their belief in their ability to reach all students, handle problems in classrooms and make a difference in students' lives. Capa (2005) revealed that the quality of teacher education programs is a significant predictor of first-year teachers' sense of efficacy. Quality teacher education programs could enhance pre-service teachers' sense of efficacy, as well as provide prospective teachers with abundance opportunities for classroom observations, guidance and practices. DarlingHammond (2010) explains that most powerful teacher education programs encourage student teachers to spend extensive time in the field, examining and applying the concepts and strategies they learn about in the course. According to the author, teacher education students learn from their instructors different approaches to make a classroom responsive while meeting the course objectives.

According to Woolfolk-Hoy (2000), pre-service teachers' self-efficacy was high throughout the training and prior to entering formal student teaching. However, it weakened during the course of student teaching. Teachers play a vital role in determining the success of student learning; thus, according to Jia et al. (2006), understanding teachers' perceptions and beliefs about themselves and their abilities is important. Besides, according to Bandura (1997), teacher's sense of efficacy can potentially influence both the kind of environment they create as well as the various instructional practices introduced in the classroom. Thus, it is important that teachers graduate from teacher education with a high level of sense of efficacy and enter the profession with full of confidence because, as asserted by FeimanNemser (2001), the first years of teaching are crucial in shaping their future performance.

\subsection{The Study}

Teacher quality matters and, in fact, it is the most important factor influencing student achievement (Rice, 2003). Student learning is enhanced when students are taught by well-prepared professionals who integrate their knowledge of instructions with a deep sense of caring about each student they teach (Stronge and Hindman, 2006). While in teacher training, teachers receive the content knowledge and skills, pedagogical knowledge and practical teaching experience through student teaching. Thus, it is believed that teachers possess some level of confidence in teaching as they graduate from teacher training institutions. Teachers' confidence in their ability to perform the actions leading to student learning is one of the important characteristics that predict teaching and learning outcomes (Poulou, 2007). Teacher's sense of efficacy was found to correlate with 
teacher commitment. According to the NCTAF (2004), one factor that makes a difference in improving a student's achievement is a knowledgeable and skilful teacher. However, researches on teacher quality have not included teacher's sense of efficacy as one of the study variables. Teacher's sense of efficacy and its impact on learning outcomes were mostly studied in isolation of other factors, such as certification, teacher academic achievement, race, gender, mastery of content knowledge and pedagogical knowledge. A review of literature on the studies on teacher quality proved this fact.

Malaysia is on the march to become a fully developed nation by 2020 and human capital lies at the core of innovations and a productive high-income economy (GM, 2010). To this end, Malaysia places a great emphasis on human capital development mainly through education and training. Currently, there are 412,720 teachers to teach 5.2 million students, with a teacher-student ratio of 1 teacher for 12.77 students. Teachers in Malaysia are trained by public and private higher education institutions and the Ministry of Education's Institutes for Teacher Training. Annually, the Ministry of Higher Education receives over 30,000 applications for teacher education programs in public institutions of higher learning for between 3000 and 4000 vacancies. The duration of a teacher education program is 4 years. The credit hours for teacher education programs range between 130 and 140, depending on the area of specialization, subject matter content and pedagogical content. All teacher education students have to undergo student teaching practicum for a period of 14 weeks in select schools, where student teachers are guided by cooperating teachers and supervised by university professors.

The present study focused on teacher education students attending a teacher training institution in one of the universities in Malaysia. Like their counterparts in other institutions, student teachers of this university will begin student teaching on completing their final semester. Invariably, teacher education students spend a little over four years in a teacher education program.

\subsection{Objectives of the Study}

The objectives of the present study were to determine the self-efficacy of pre-service teachers of a select university in Malaysia and to determine the association between self-efficacy and several independent variables.

\subsection{Research Questions}

The study was designed to find answers to the following research questions: (1) How efficacious are pre-service teachers in their ability to execute the practices of teaching? (2) What is the relationship between academic achievement and pre-service teacher' self-efficacy? (3) Does pre-service teachers' self-efficacy differ as a function of gender, academic major, career choice and educational aspiration?

\section{MATERIALS AND METHODS}

A descriptive correlation research method was adopted for the study. The questionnaire was divided into two parts. Part A contained questions about respondents' background information, such as age, gender, academic major, choice of teaching and educational aspiration. Part B consisted of measures of teacher's sense of efficacy.

\subsection{Measure of Teacher's Sense of Efficacy}

Teacher's sense of efficacy was measured using Teacher Sense of Efficacy Scale (TSES) developed by Tschannen-Moran and Hoy (2001) and adopted by many researchers to assess teacher's sense of efficacy (e.g., O'Neill and Stephenson, 2012; Mergler and Tangen, 2010; Charalambous et al., 2008; Fives et al., 2007; Poulou, 2007; Klassen et al., 2009). TSES consists of 24 items with three sub-scales: efficacy for student engagement, efficacy for instructional strategies and efficacy for classroom management. TSES uses a ninepoint Likert scale with an overall reliability of 0.94 . Most of the studies mentioned above used the original nine-point Likert scale. Poulou (2007); Atay (2007); Bakar and Mohamed (2008) and Guo et al. (2011), however, used a five-point Likert scale of TSES.

Originally, TSES asks the respondents "How much...". Whereas, Atay (2007) and Poulou (2007) asked the respondents "How well/To what extent...". Since efficacy is a measure of the confidence one has to execute the tasks given to him or her, we made slight modification to the presentation of the scale by asking the respondents to indicate the level of confidence they have with regard to each of the teaching activities/tasks. For example, we asked them "How confident are you to: use a variety of assessment strategies", “...control disruptive behaviour in the classroom" and "...help student value learning". Students responded to the questions on a five-point Likert scale between 1 (not at all confident) and 5 (very confident). The instrument was pilottested to ascertain its reliability. The overall reliability of the scale was 0.94. For the sub-scale "efficacy in student engagement", reliability was 0.83 ; for "efficacy in instructional strategies", it was 0.87 ; and for "efficacy in classroom management", it was 0.90 . 


\section{RESULTS}

The participants for this study were drawn from a population of pre-service teachers enrolled in a teacher education program in one of the universities in Malaysia. Of the total sample $(\mathrm{n}=675), 26.5 \%$ were men and $73.5 \%$ were women. About $41 \%$ of the respondents were undergoing re-certification (from a diploma to a bachelor's degree) and 59\% came fresh after school. The sample of pre-service teachers had a mean age of 28.1 $(\mathrm{SD}=5.1)$ and were of different subject majors. When asked whether they would take up teaching once they graduated, $90 \%$ said they will go into teaching and $80 \%$ expressed their wish to continue in the teaching profession. They had high educational aspiration and $90 \%$ of them had the desire to go for further studies if chances may arise.

The present study aimed to assess pre-service teachers' perception of their sense of efficacy and the findings are summarized in Table 1. Accordingly, preservice teachers reported they can confidently handle the classroom teaching tasks. Their confidence level for each sub-scale was almost similar. The outcomes of the items assessed are presented in Table 1.

The second objective of the study was to determine the association between pre-service teachers' sense of efficacy and independent variables. A Pearson's correlation analysis was carried out to determine the association between teacher's sense of efficacy and his or her academic performance. According to the results, a significant correlation was found between teacher's sense of efficacy and academic performance $(r=0.15 ; p<0.05)$. We also hypothesized that teacher's sense of efficacy does not differ as a function of gender. T-test results showed that teacher's sense of efficacy differs significantly as a function of gender $\left(\mathrm{t}_{672}=6.47 ; \mathrm{p}<0.05\right)$. Male students were significantly more efficacious $(\mathrm{M}=4.11$; $\mathrm{SD}=0.35)$ than female students $(\mathrm{M}=3.92, \mathrm{SD}=0.34)$. The present study also attempted to examine teacher's sense of efficacy with respect to career choice and educational aspiration. It was found that teacher's sense of efficacy differed significantly between students who would opt for teaching job and those who did not $\left(\mathrm{t}_{672}=6.04 ; \mathrm{p}<0.05\right)$.

Table 1. Means and standard deviations of student teachers' self-efficacy

\begin{tabular}{|c|c|c|}
\hline Items of scale & Mean & SD. \\
\hline General efficacy & 3.98 & 0.36 \\
\hline Student engagement & 4.01 & 0.39 \\
\hline How confident are you to get through to the most difficult students & 3.93 & 0.60 \\
\hline How confident are you to help students think critically & 3.97 & 0.53 \\
\hline How confident are you to motivate students who show low interest in school work & 4.06 & 0.56 \\
\hline How confident are you to get students to believe they can do well in school work & 4.15 & 0.55 \\
\hline How confident are you to help your students value learning & 4.08 & 0.53 \\
\hline How confident are you to foster student creativity & 4.00 & 0.62 \\
\hline How confident are you to improve the understanding of a student who is failing & 4.03 & 0.57 \\
\hline How confident are you to assist families in helping their children do well in school & 3.79 & 0.66 \\
\hline Instructional strategy & 4.00 & 0.43 \\
\hline How confident are you to respond to difficult questions from your students & 3.95 & 0.59 \\
\hline How confident are you to gauge student comprehension of what you have taught & 4.06 & 0.53 \\
\hline How confident are you to craft good question for your students & 3.99 & 0.59 \\
\hline How confident are you to adjust your lessons to the proper level for individual student & 3.96 & 0.62 \\
\hline How confident are you to use a variety of assessment strategies & 4.02 & 0.57 \\
\hline How confident are you to provide an alternative explanation or an example when students are confused & 4.08 & 0.58 \\
\hline How confident are you to implement alternative strategies in your classroom & 4.00 & 0.59 \\
\hline How confident are you to provide appropriate challenges for very capable students & 3.94 & 0.62 \\
\hline Classroom management & 4.00 & 0.46 \\
\hline How confident are you to control disruptive behaviour in the classroom & 4.03 & 0.63 \\
\hline How confident are you to make your expectations clear about student behavior & 3.91 & 0.63 \\
\hline How confident are you to establish routines to keep activities running smoothly & 4.05 & 0.59 \\
\hline How confident are you to get children to follow classroom rules & 4.03 & 0.60 \\
\hline How confident are you to establish a classroom management system with each group of student & 4.06 & 0.54 \\
\hline How confident are you to calm a student who is disruptive and noisy & 3.96 & 0.60 \\
\hline How confident are you to keep few problem students from ruining an entire lesson & 3.87 & 0.63 \\
\hline How confident are you to respond to defiant student & 4.07 & 0.58 \\
\hline
\end{tabular}


Table 2. Means and standard deviations of teacher's sense of efficacy by content major

\begin{tabular}{lrlll}
\hline Content major's & $\mathrm{n}$ & Mean & $\mathrm{SD}$ & Test \\
\hline Vocational & 447 & 3.94 & 0.36 & $\mathrm{~F}_{3,668}=9.86 ; \mathrm{p}<0.05$ \\
Science and mathematics & 145 & 3.99 & 0.35 & \\
Physical education & 49 & 4.02 & 0.25 & \\
Language & 31 & 4.28 & 0.31 & \\
\hline
\end{tabular}

Respondents who have planned to join the teaching force proved more efficacious $(\mathrm{M}=4.00, \mathrm{SD}=0.34)$ than those without a plan to do so $(\mathrm{M}=3.74, \mathrm{SD}=0.38)$. A ttest was carried out to determine whether teacher's sense of efficacy is a function of his or her educational aspiration. There was a significant difference in efficacy with regard to educational aspiration $\left(\mathrm{t}_{672}=2.02, \mathrm{p}=\right.$ $0.05)$. Respondents who aspire for a post-graduate degree were significantly more efficacious $(\mathrm{M}=3.99$, $\mathrm{SD}$. $=0.36$ ) than those who were content with their bachelor's degrees $(\mathrm{M}=3.89, \mathrm{SD}=0.36)$. It was also the object of this research to determine whether teacher's sense of efficacy differed across content majors. A oneway ANOVA showed that teacher's sense of efficacy differed across content majors $\left(\mathrm{F}_{3,668}=9.86, \mathrm{p}<0.05\right)$ among student teachers. Moreover, the students who majored in language were more efficacious that students of other majors (vocational, science, mathematics and physical education). There was no significant difference in teachers' sense of efficacy among student teachers who majored in vocational, science, mathematics and physical education (Table 2).

\section{DISCUSSION}

Teaching puts into work a wide range of abilities and characteristics of a teacher. One of the major characteristics of promise to teaching quality is teacher's sense of efficacy. Efficacious teachers are able to contribute a lot to the success of teaching and learning. Thus, teacher education programs must aim to develop this attribute among teacher education students. Teacher preparation usually addresses content knowledge, pedagogical background, mentoring experience and teaching efficacy. A study on TSES is significant because a teacher with a high TSES is presumed to take every step to ensure positive outcomes out of teaching functions. He or she will, in turn, aim to develop selfefficacy among students as well as ensure excellent academic achievement.

Overall, the present study found that teacher education students in the specific teacher training institution presented a high sense of efficacy. The present findings agree well with Ajay's study (2007) on
Turkish pre-service teachers whose TSES mean score of 3.97 was very much close to our score of 3.98. However, our TSES score differed, although marginally, from Poulou (2007) and Guo et al. (2011) reported average mean scores of 3.56 and 3.60, respectively, for preschool teachers' self-efficacy. On the other hand, Bakar et al. (2008) on a study of science student teacher self-efficacy reported a mean score of 3.91, slightly lower than the current mean score of 3.98. Several other studies, which used a nine-point TSES scale, reported similar findings.

In a study to determine pre-service teachers' selfefficacy following the student teaching experiences, Knoblauch and Hoy (2008) reported that the mean score for pre-service teacher's sense of efficacy prior to the student teaching experience was 6.79. O'Neill and Stephenson (2012) reported the final-year Australian preservice teachers' sense of efficacy on the TSES scale to be 6.95 out of 9 . In a study to explore potential sources of teachers' self-efficacy, Tschannen-Moran and Hoy (2007) reported that mean self-efficacy score for novice teachers was 6.87 while that for career teacher was 7.29, suggesting that experience plays a role in teachers' belief about their ability to handle the tasks effectively. The findings of many studies on TSES across different cultures (American, Australian, Chinese and Malaysian) have been similar, although different instruments may have been used to assess TSES.

It is understandable that the efficacy of pre-service teachers is merely an indicator of how confident they are to face the real challenge. However, teaching efficacy is expected to improve once they begin their teaching practice and as Bandura (1997) suggests, mastery of difficult tasks heightens the feeling of efficacy. According to Tschannen-Moran and Hoy (2007), experience plays an important role in the development of TSES. Steele (2010) believes that success in teaching usually requires hard work and perseverance. Thus, preservice teachers must be given opportunities to experience teaching through peer teaching, student teaching and getting attached to schools prior to student teaching. These experiences should help improve their TSES.

The present study also revealed that male pre-service teachers are significantly efficacious than female preservice teachers. This finding agrees with the report of Brookhart and Freeman (1992), which stated that new teacher candidates, particularly male candidates, had a high level of self-confidence. To study how TSES differed by gender is interesting, but literature to this end are hard to find. However, the present trends point out to the need for female teachers to develop a high TSES, especially with growing demands from parents to have 
their children taught by female teachers. Moreover, female teachers must exhibit high efficacy in the light of the fact that the explosion of ICT has resulted in the rise of social problems among school children. In Malaysia, female teachers greatly outnumber male teachers; there may be one male teacher for every two female teachers. Thus, the responsibility of educating the children is highly tasked to female teachers. It requires teachers to be highly efficacious or highly confident in performing their tasks and as Skaalvik and Skaalvik (2007) remarked, without confidence in their abilities, teachers may not be successful or implement less effective instructional strategies and could be more likely to leave the field as a result.

Putman (2012) suggested that institutions of higher learning must create opportunities for pre-service teachers to explicitly examine their efficacy beliefs and confidence in their abilities while engaged in coursework and field experience. If it is to be done, it is more likely suitable to be done after pre-service teachers have enrolled in education related course, especially those that provide pedagogical knowledge and skills and it should be done throughout their teacher education training. In that way, we can see what factors contribute to their efficacy. It is also interesting to know why female teacher education students in this particular study were less efficacious compared to their male counterparts. Is it because of the homogeneity of the population of student teachers?

\section{CONCLUSION}

From the present study the following conclusion can be made:

- Teacher sense of efficacy among Malaysian preservice teachers is high. They believe they are able to perform the task required of them

- There was a significant correlation between teachers' sense of efficacy and academic achievement and it teachers' sense effiacy differ as a function gender. Male pre-service teachers were found to be more efficacious than female pre-service teachers

- Educational aspiration was related to teachers' sense of efficacy

- Teachers' sense of efficacy differ across pre-service teachers prohgram of studies

\section{REFERENCES}

Akiba, M., G.K. LeTendre and J.P. Scribner, 2007. Teacher quality, opportunity gap and national achievement in 46 Countries. Educ. Res., 36: 369387. DOI: 10.3102/0013189X07308739
Allinder, R.M., 1994. The relationship between efficacy and the instructional practices of special education teachers and consultants. Teacher Educ. Special Educ., 17: 86-95. DOI: 10.1177/088840649401700203

Ashton, P.T. and R.B. Webb, 1986. Making a Difference: Teachers' Sense of Efficacy and Student Achievement. 1st Edn., Longman, New York, ISBN-10: 0582284805, pp: 225.

Atay, D., 2007. Beginning teacher efficacy and the practicum in EFL context. Teacher Dev., 11: 203219. DOI: $10.1080 / 13664530701414720$

Bakar, A.R. and S. Mohamed, 2008. Teacher sense of efficacy among Malaysian agriculture student teachers. Int. J. Hum., 6: 137-144.

Bakar, A.R., M.M. Konting, R. Jamian and N. Lyndon, 2008. Teaching efficacy of Universiti Putra Malaysia science student teachers. College Student J., 42: 493-509.

Bandura, A., 1986. Social Foundations of Thought and Action: A Social Cognitive Theory. 1st Edn., Prentice-Hall, Englewood Cliffs, NJ., pp: 617.

Bandura, A., 1997. Self-Efficacy: The Exercise of Control. 1st Edn., Freeman, New York, ISBN-10: 0716728508, pp: 604.

Brookhart, S.M. and D.J. Freeman, 1992. Characteristics of entering teacher candidates. Rev. Educ. Res., 62: 37-60. DOI: 10.3102/00346543062001037

Capa, Y., 2005. Factors influencing first-year teachers' sense of efficacy. Ph.D. dissertation. The Ohio State University, United States-Ohio.

CTQ, 2006. Where teachers are central to improving schools.

Charalambous, Y.C., G.N. Philippou and L. Kyriakides, 2008. Tracing the development of pre-service teachers' efficacy beliefs in teaching mathematics during fieldwork. Educ. Stud. Math., 67: 125-142. DOI: 10.1007/s10649-007-9084-2

Cohen-Vogel, L., 2005. Federal role in teacher quality: "Redefinition" or policy alignment? Educ. Policy, 19: 18-43. DOI: 10.1177/0895904804272246

Colodarci, T., 1992. Teachers' sense of efficacy and commitment to teaching. J. Exp. Educ., 60: 323-337.

Darling-Hammond, L. and P. Youngs, 2002. Defining "highly qualified teachers": What does "scientifically-based research" actually tell us? Educ. Res., 31: 13-25. DOI: 10.3102/0013189X031009013

Darling-Hammond, L., 2010. Teacher education and the American future. J. Teacher Educ., 61: 35-47. DOI: $10.1177 / 0022487109348024$ 
Darling-Hammond, L., R. Chung and F. Frelow, 2002. Variation in teacher preparation: How well do different pathways prepare teachers to teach? J. Teacher Educ., 53: 286-302. DOI: 10.1177/0022487102053004002

Early, D., D. Bryant, R. Pianta, R. Clifford and M.S. Burchinal et al., 2006. Are teachers' education, major and credentials related to classroom quality and children's academic gains in pre-kindergarten? Early Childhood Res. Q., 21: 174-195. DOI: 10.1016/j.ecresq.2006.04.004

Early, D., K.L. Maxwell, M. Burchinal, S. Alva and R.H. Bender et al., 2007. Teachers' education, classroom quality and young children's academic skills: Results from seven studies of preschool programs. Child Dev., 78: 558-580. DOI: 10.1111/j.14678624.2007.01014.x

GM, 2010. Tenth Malaysia Plan 2022-2015. Economic Planning Unit, Kuala Lumpur.

Feiman-Nemser, S., 2001. From preparation to practice: Designing a continuum to strengthen and sustain teaching. Teachers College Record, 103: 1013-1055. DOI: $10.1111 / 0161-4681.00141$

Fives, H., D. Hamman and A. Oliveraz, 2007. Does burn-out begin with student teaching? Analyzing efficacy, burnout and support during the studentteaching semester. Teaching Teacher Educ., 23: 916-934. DOI: $10.1016 /$ j.tate.2006.03.013

Garcia, D., 2004. Exploring connection between the construct of teacher efficacy and family involvement practices. Urban Educ., 39: 290-315. DOI: 10.1177/0042085904263205

Gibson, S. and M. Dembo, 1984. Teacher efficacy: A construct validation. J. Educ. Psychol., 76: 569-582. DOI: 10.1037/0022-0663.76.4.569

Guo, Y., L.M. Justice, B. Sawyer and V. Tompkins, 2011. Exploring factors related to pre-school teachers' self-efficacy. Teach. Teacher Educ., 27: 961-968. DOI: 10.1016/j.tate.2011.03.008

Guo, Y., S.B. Piasta, L.M. Justice and J. Kaderavek, 2010. Relations among pre-school teachers' selfefficacy, classroom quality and children's language and literacy gains. Teach. Teacher Educ., 26: 10941103. DOI: 10.1016/j.tate.2009.11.005

Hall, B., W. Burley, M. Villeme and L. Brockmeier, 1992. An attempt to explicate teacher efficacy beliefs among first year teachers. Proceedings of the Annual Meeting of the American Educational Research Association, (AERA’ 92), San Francisco.
Jia, Y., Z.R. Eslami and L. Burlbaw, 2006. ESL teachers' perceptions and factors influencing their use of classroom-based reading assessment. Bilingual Res. J., 29: 459-482.

Justice, L.M., A. Mashburn, B. Hamre and R. Pianta, 2008. Quality of language and literacy instruction in preschool classrooms serving at-risk pupils. Early Childhood Res. Q., 23: 51-68. DOI: 10.1016/j.ecresq.2007.09.004

Klassen, R.M., M. Bong, W.H. Chong, V.S. Huan and I.Y.F. Wong et al., 2009. Exploring the validity of a teacher's self-efficacy scale in five countries. Contemporary Educ. Psychol., 34: 67-76. DOI: 10.1016/j.cedpsych.2008.08.001

Knoblauch, D. and A.W. Hoy, 2008. Maybe I can teach those kids. The influence of contextual factors on student teachers' efficacy beliefs. Teach. Teacher Educ., 24: 166-179. DOI: 10.1016/j.tate.2007.05.005

Mergler, A.G. and D. Tangen, 2010. Using microteaching to enhance teacher efficacy in preservice teachers. Teach. Educ., 21: 199-210. DOI: 10.1080/10476210902998466

Milner, H.R., 2001. A qualitative investigation of teachers' planning and efficacy for student engagement. Unpublished Dissertation, The Ohio State University, Columbus, $\mathrm{OH}$.

Milner, H.R., 2002. A case study of an experienced teacher's self efficacy and persistence through crisis situations: Theoretical and practical considerations. High School J., 86: 28-35. DOI: 10.1353/hsj.2002.0020

Mitchell, K.J., D.Z. Robinson, B.S. Plake and K.T. Knowles, 2001. Testing teacher candidates: The role of licensure tests in improving teacher quality. National Academy Press, Washington, DC.

NA, 2007. Study of teacher preparation programs in the United States.

NCTAF, 2004. Helping students learn: An online anthology on student achievement.

O'Neill, S. and J. Stephenson, 2012. Exploring Australian pre-service teachers sense of efficacy, its sources and some possible influences. Teach. Teacher Educ., 28: 535-545. DOI: 10.1016/j.tate.2012.01.008

Owings, W.A., L.S. Kaplan, J. Nunnery, R. Marzano and S. Myran et al., 2006. Teacher Quality and Troops to Teachers: A national study with implications for principals. NASSP Bull., 90: 102-131. DOI: $10.1177 / 0192636506289023$ 
Poulou, M., 2007. Personal teaching efficacy and its sources: Student teachers' perceptions. Educ. Psychol., 27: 191-218. DOI: $10.1080 / 01443410601066693$

Putman, S.M., 2012. Investigating teacher efficacy: Comparing pre-service and in-service teachers with different levels of experience. Action Teacher Educ., 34: 26-40. DOI: 10.1080/01626620.2012.642285

Rice, J.K., 2003. Teacher Quality: Understanding the Effectiveness of Teacher Attributes. 1st Edn., Economic Policy Institute, Washington, DC., ISBN10: 1932066063 , pp: 64.

Roberts, J.L., 2006. Teachers of Secondary Gifted Students. In: The Handbook of Secondary Gifted Education. Dixon, F.A. and S.M. Moon (Eds.), Prufrock, Waco, TX., ISBN-10: 1593631782, pp: 567-580.

Skaalvik, E. and S. Skaalvik, 2007. Dimensions of teacher self-efficacy and relations with strain factors, perceived collective teacher efficacy and teacher burnout. J Educ. Psychol., 99: 611-625. DOI: 10.1037/0022-0663.99.3.611

Steele, N.A., 2010. Three characteristics of effective teachers. Update: Appli. Res. Music Educ., 28: 7178. DOI: $10.1177 / 8755123310361769$

Stronge, J.H. and J.L. Hindman, 2006. The Teacher Quality Index: A Protocol for Teacher Selection. 1st Edn., Association for Supervision and Curriculum Development (ASCD), Alexandria: VA., ISBN-10: 1416602720, pp: 138 .
Tschannen-Moran, M. and A. Woolfolk Hoy, 2007. The differential antecedents of self-efficacy beliefs of novice and experienced teachers. Teach. Teacher Educ., 23: 944-956. DOI: 10.1016/j.tate.2006.05.003

Tschannen-Moran, M. and A.W. Hoy, 2001. Teacher efficacy: Capturing and elusive construct. Teach. Teacher Educ., 17: 783-805. DOI: 10.1016/S0742051X(01)00036-1

Tschannen-Moran, M., A. Hoy, A.E. Woolfolk and W.K. Hoy, 1998. Teacher efficacy: Its meaning and measures. Rev. Educ. Res., 68: 2002-248. DOI: $10.2307 / 1170754$

Wayne, A.J. and P. Youngs, 2003. Teacher characteristics and student achievement gains: A review. Rev. Educ. Res., 73: 89-122. DOI: 10.3102/00346543073001089

Woolfolk-Hoy, A., 2000. Changes in teacher efficacy during the early years of teaching. The Ohio State University.

Yost, R., 2002. I think I can: Mentoring as a mean of enhancing teacher efficacy. Clear. House, 75: $195-$ 197. DOI: $10.1080 / 00098650209604930$ 